\title{
PENGOLAHAN DATA LANDSAT DAN GRAVITASI SEBAGAI INDIKASI PANASBUMI DAERAH RANA KULAN, NTT
}

\section{LANDSAT AND GRAVITY DATA PROCESSING AS A GEOTHERMAL INDICATION OF THE RANA KULAN, NTT}

\author{
Pangeran Brandon $\operatorname{Imran}^{1^{*}}$, Erwin Fernanda ${ }^{2}$, Sthevanie Dhita Sudrazat ${ }^{3}$ \\ 1,2,3Teknik Geofisika, Fakultas Teknologi Eksplorasi dan Produksi, U niversitas Pertamina
}

Received: 2020, October $27^{\text {th }}$ Accepted: 2021, M arch $7^{\text {th }}$

\section{Keyword:}

Geothermal;

Gravity;

Landsat 8;

Non-Linear Inversion;

SVD.

\section{Corespondent Email:}

brandonimran@gmail.com

\section{How to cite this article: Imran, P.B., Fernanda, E., \& Sudrazat, S.D. (2021). Pengolahan Data Landsat dan Gravitasi Sebagai Indikasi Panasbumi Daerah Rana Kulan, NTT. Jurnal Geofisika Eksplorasi, 07(01), 41-51.}

(c) 2021 JGE (Jurnal Geofisika Eksplorasi). This article is an open access article distributed under the

\begin{abstract}
Abstrak. Pemanfaatan panasbumi Indonesia hingga kini baru mencapai 4\% dari seluruh cadangan yang tersedia. Sedangkan Indonesia memiliki cadangan panasbumi sebesar 29000 MW yang merupakan 40\% dari cadangan dunia. Oleh karena itu, dibutuhkan pemetaan daerah prospek panasbumi untuk mendukung studi awal dalam melakukan eksplorasi panasbumi. Pengolahan data Landsat 8 dilakukan dengan metode NDVI (Normalized Difference Vegetation Index) sedangkan data gravitasi menggunakan metode SVD (Second Vertical Derivative) serta Inversi Non-Linear. Penelitian ini menghasilkan peta suhu permukaan tanah, peta persebaran anomali gravitasi dan model $2 \mathrm{D}$ struktur geologi daerah penelitian yang didukung oleh peta geologi. Hasil pengolahan dan interpretasi data menunjukkan bahwa patahan merupakan struktur utama dan minor di Rana Kulan yang berasosiasi dengan suhu permukaan tanah yang tinggi. Dengan demikian, hal ini menunjukkan bahwa daerah Rana Kulan memiliki potensi panasbumi yang dapat dikaji lebih lanjut pada penelitian selanjutnya.
\end{abstract}

\footnotetext{
Abstract. Utilization of Indonesia's geothermal energy has only reached $4 \%$ of all available reserves. M eanwhile, Indonesia has geothermal reserves of 29000 M W which constitute $40 \%$ of the world's reserves. Therefore, it is necessary to map the geothermal prospect area to support the initial study in conducting geothermal exploration. Landsat 8 data processing was carried out using the NDVI (N ormalized Difference Vegetation Index) method while the gravity data used the SVD (Second Vertical Derivative) method and Non-Linear Inversion. This research produces a map of land surface temperature, a map of the distribution of gravity anomalies and a 2D model of the geological structure of the study area supported by a geological map. The results of data processing and interpretation indicate that the fault is a major and minor structure in Rana Kulan which is associated with high soil surface temperatures. Thus, this
} 
terms and conditions of the Creative Commons Attribution (CC BY NC) indicates that the Rana Kulan area has geothermal potential which can be studied further in further research

\section{PENDAHULUAN}

Cadangan bahan bakar fosil semakin menipis seiring berjalannya waktu, sedangkan kebutuhan energi semakin meningkat, sehingga dibutuhkan energi terbarukan untuk membantu memenuhi kebutuhan tersebut, salah satunya adalah energi panasbumi. Energi panasbumi merupakan salah satu energi yang dapat diperbaharui untuk dapat mencukupi ketersedian energi selama kondisi lingkungan dapat terjaga keseimbangannya. Pemanfaatan energi panasbumi di Indonesia baru mencapai 4\% dari 29000 MW cadangan yang tersedia (Hutahaean \& Silaban, 2017). Sehingga pemetaan panasbumi secara menyeluruh dibutuhkan untuk meningkatkan efisiensi pada eksplorasi lebih lanjut. Salah satu daerah yang menjadi perhatian khusus penelitian ini adalah Rana Kulan, NTT, Indonesia.

Berdasarkan laporan Kementerian ESDM, Daerah Rana Kulan memiliki bukti manifestasi berupa mata air panas dengan suhu $37.3^{\circ} \mathrm{C}$ (Direktorat Panas Bumi, 2017). Penelitian ini dilakukan untuk menganalisa lebih lanjut pemetaan Land Surface Temperature dan anomali gravitasi untuk memperluas prospek panasbumi sehingga peluang menemukannya potensi panasbumi lebih besar. Dengan demikian, diharapkan penelitian ini dapat meningkatkan efisiensi studi awal untuk penentuan titik produksi panasbumi di Indonesia.

Adapun tujuan dari penelitian ini, yaitu untuk menentukan karakteristik struktur geologi berdasarkan hasil SVD dan inversi nonlinear pada data gravitasi, menentukan karateristik suhu permukaan tanah daerah penelitian berdasarkan hasil Land Surface Temperature (LST), serta menentukan daerah potensi panasbumi berdasarkan hasil integrasi antara Land Surface Temperature dan struktur geologi.

\section{TINJAUAN PUSTAKA}

\subsection{Geologi Regional}

Daerah Rana Kulan termasuk dalam busur vulkanik (volcanic arc) di kepulauan Nusa Tenggara yang terbentuk akibat subduksi lempeng Indo-A ustralia di bawah busur SundaBanda pada masa Tersier (Darman, 2000). Pada daerah ini terdapat struktur geologi berupa sesar normal sebagai pengontrol kemunculan mata air panas, sesar geser jurus menganan, lipatan, dan kelurusan. (Kasbani, 2009) menyatakan bahwa sistem panasbumi disusun oleh batuan vulkanik menengah yang mengandung andesit-basalt.

Berdasarkan Peta Geologi Lembar Ruteng skala 1:125,000 oleh Koesoemadinata dkk. (1994), daerah penelitian (Gambar 1 dan 2) terdiri atas enam formasi, yaitu Formasi Kiro (satuan batuan breksi dengan komponen batuan andesit dan basal, lava dan tuf dengan sisipan batupasir tufan), Formasi Bari (satuan batuan batugamping berselingan dengan batugamping pasiran), Formasi Nangapanda (satuan batuan batupasir yang memiliki komponen andesit dan basalt, dan batu gamping), Formasi Waihekang (satuan batuan batugamping klastika), Formasi Laka (satuan batuan Tuf, setempat berselingan dengan batupasir tufan; setempat bersisipan batupasir gampingan) dan Formasi Diorit Kuarsa.

\subsection{M etode Gravitasi}

Metode gayaberat (gravitasi) merupakan metode geofisika yang didasarkan oleh H ukum Newton tentang gravitasi, seperti yang ditunjukkan pada Gambar 3. Dengan H ukum Gravitasi Newton dinyatakan bahwa gaya tarik menarik antara dua buah benda adalah sebanding dengan massa kedua benda tersebut dan berbanding terbalik dengan jarak antara pusat massa kedua benda tersebut yang dapat 
dihitung dengan persamaan di bawah ini (Hinze dkk., 2013).

$$
F=\mathrm{G} \frac{M m}{R^{2}} \dot{r}
$$

Dimana, F (N) merupakan gaya tarikmenarik antara dua benda yang memiliki massa, G $\left(6.67 \times 10^{-11} \mathrm{Nm}^{2} \mathrm{~kg}^{2}\right)$ adalah konstanta gravitasi, $\mathrm{M}(\mathrm{kg})$ adalah massa benda pertama, $\mathrm{m}(\mathrm{kg})$ adalah massa benda kedua, dan $\mathrm{R}(\mathrm{m})$ adalah jarak antara kedua benda.

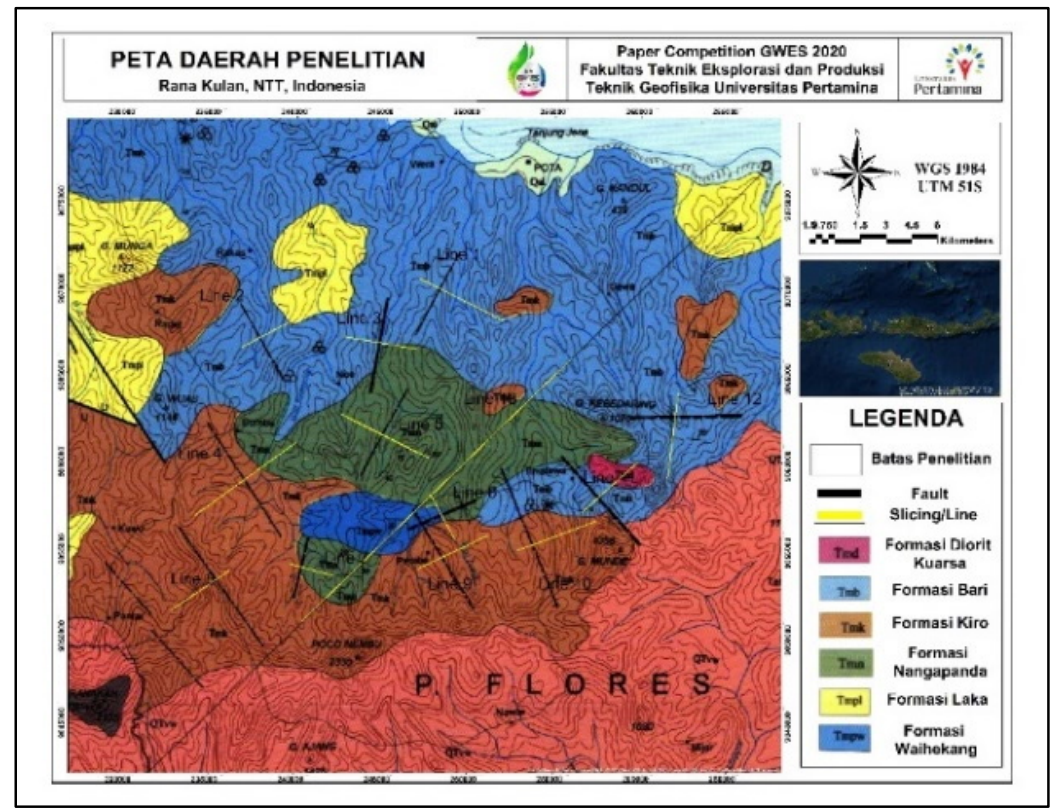

Gambar 1. Peta litologi daerah penelitian.

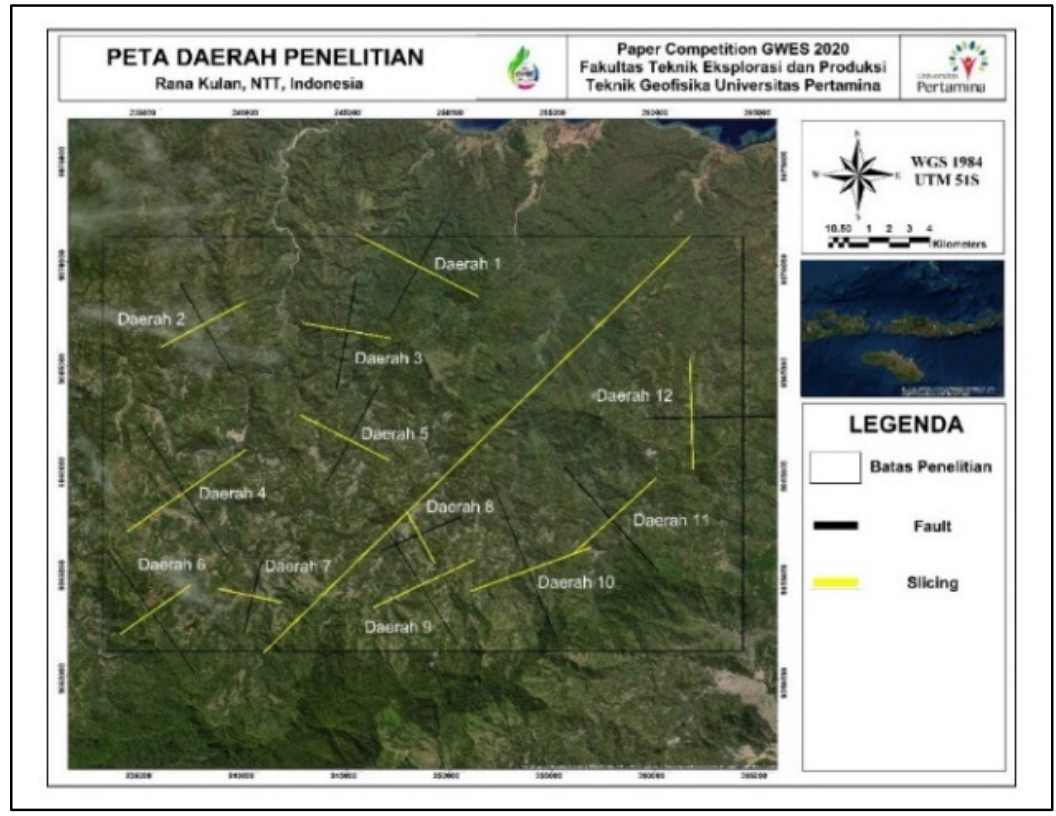

Gambar 2. Peta sesar dan slicing SVD. 


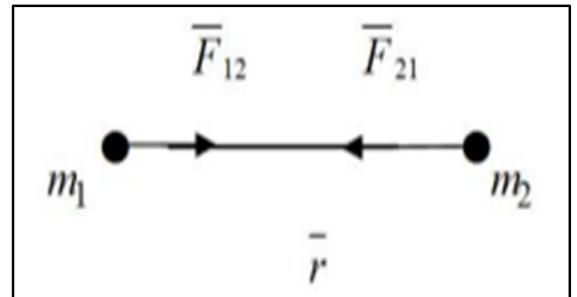

Gambar 3. Gaya tarik menarik antara $m_{1}$ dan $m_{2}$ pada jarak $r$.

\subsection{Second Vertical Derivative(SVD)}

M etode Second Vertical Derivative (SVD) digunakan untuk mendukung interpretasi jenis struktur data anomali Bouguer yang diakibatkan oleh struktur patahan turun atau patahan naik (Sarkowi, 2011). Persamaan SV D (Telford dkk., 1990) adalah sebagai berikut:

$$
\frac{\delta^{2} \Delta g}{\delta z^{2}}=\left(\frac{\delta^{2} \Delta g}{\delta x^{2}}+\frac{\delta^{2} \Delta g}{\delta y^{2}}\right)
$$

Untuk data 1D persamaannya menjadi persamaan (3) berikut:

$$
\frac{\delta^{2} \Delta g}{\delta z^{2}}=-\left(\frac{\delta^{2} \Delta y}{\delta x^{2}}\right)
$$

Berdasarkan penelitian Sarkowi (2011), jenis struktur sesar dapat dilihat dari hasil slicing data SVD. A pabila nilai absokut maksimum kurva lebih besar disbanding nilai obsolut minimum kurva maka jenis patahannya adalah patahan normal, dan sebaliknya menunjukkan patahan naik.

$$
\begin{aligned}
& \left|\frac{\partial^{2} g}{\partial}\right|_{\text {maks }}>\left|\frac{\partial^{2} g}{\partial z^{2}}\right|_{\text {min }} \\
& \left|\frac{\partial^{2} g}{\partial}\right|_{\text {maks }}<\left|\frac{\partial^{2} g}{\partial z^{2}}\right|_{\text {min }}
\end{aligned}
$$

\subsection{Inversi Non-Linear}

Perhitungan inversi non-linear menggunakan turunan rumus metode N ewton dengan asusmi $\mathrm{H}=0$ (matriks $\mathrm{H}$ essian) seperti yang ditunjukkan oleh rumus berikut:

$$
\underset{\left.\left.g\left(m_{n}\right)\right]\right)}{m_{n+1}}=m_{n}+\left(J_{n}^{T} J_{n}\right)^{-1} \cdot\left(J _ { n } ^ { T } \left[d_{n}-\right.\right.
$$

Dengan $g n=(m 1, m 2, \ldots, m k)=d n$, untuk setiap $\mathrm{k}$ bilangan asli, $\mathrm{mk}(0)$ adalah parameter awal ke - k, dan matriks Jacobian dirumuskan sebagai berikut:

$$
\begin{gathered}
J= \\
{\left[\begin{array}{cccc}
\left(\frac{\partial g}{\partial m_{1}}\right)_{1}\left(m_{1}(0)\right) & \ldots & \left(\frac{\partial g}{\partial m_{k}}\right)_{1} & \left(m_{k}(0)\right) \\
\vdots & \ddots & \vdots \\
\left(\frac{\partial g}{\partial m_{1}}\right)_{n}\left(m_{1}(0)\right) & \ldots & \left(\frac{\partial g}{\partial m_{k}}\right)_{n} & \left(m_{k}(0)\right)
\end{array}\right] \text { (7) }}
\end{gathered}
$$

\subsection{LST (Land Surface Temperature)}

Suhu permukaan merupakan suhu bagian terluar dari suatu objek yang bergantung pada sifat fisik permukaan objek berupa emisivitas. Pemetaan suhu permukaan atau Land surface temperatur dilakukan untuk mengetahui wilayah distribusi spasial yang mempengaruhi kenaikan temperatur permukaan tanah. Objek yang memiliki emisivitas, kapasitas panas rendah, dan konduktivitas termal tinggi akan mengalami peningkatan suhu permukaan, sedangkan sebaliknya, akan mengalami penurunan suhu permukaan (A riyadi, 2007).

Untuk mendapat LST atau suhu permukaan tanah yang dikoreksi emisivitas $\mathrm{T}_{S}$ dihitung sebagai berikut:

$$
T_{S}=\frac{\mathrm{BT}}{\left\{1+\left[\left(\frac{\lambda \mathrm{BT}}{\rho}\right) \ln \varepsilon_{\lambda}\right]\right\}}
$$

Dimana $T_{s}$ adalah LST dalam Celcius, BT pada sensor $\mathrm{BT}\left({ }^{\circ} \mathrm{C}\right), \lambda$ adalah Panjang gelombang emisi yang dipancarkan (dimana respon puncak dan rata-rata dari batasan gel ombang ( $\lambda$ $=10,895$ (Markham \& Barker, 1985) akan digunakan), $\varepsilon_{\lambda}$ adalah emisivitas berdasarkan kalkulasi oleh W eng dkk. (2004).

Dalam menentukan nilai LST dibutuhkan beberapa koreksi seperti koreksi atmosfer dengan memasukkan band 10. Kemudian dilakukan konversi radiasi atmosfer ke sinar inframerah menggunakan data spectral radiance ke brightness temperature menggunakan konstanta termal dalam file LANDSAT. 


\section{METODE PENELITIAN}

\subsection{Data Penelitian}

Untuk data penelitian yang digunakan terdiri dari 2 jenis data yaitu:

a. Data Utama

Data utama yang digunakan dalam penelitian ini adalah data gravitasi dan data Landsat 8. Data gravitasi didapatkan dari data satelit yang diunduh pada website Topex.org. Sedangkan data Landsat 8 didapatkan dari data satelit pada website USGS. Data Landsat 8 merupakan data yang digunakan untuk metode penginderaan jauh yang memiliki 11 macam saluran (band) dengan resolusi spasial yang berkisar $15 \times 15$ meter hingga $100 \times 100$ meter (U nited States Geological Survey, 2016).

\section{b. Data Pendukung}

Data Pendukung merupakan data yang digunakan untuk mendukung hasil analisa data utama. Data Pendukung yang digunakan di penelitian ini adalah peta lembar geologi Ruteng, data geologi, dan literatur yang terkait dengan pembahasan.

\subsection{Batasan Masalah}

A dapun batasan masalah pada penelitian ini antara lain:

a. Daerah slicing tegak lurus dengan arah sesar pada peta lembar geologi Ruteng dan dapat dilihat pada Gambar 2.

b. Belum ada validasi dari hasil pengolahan data di lapangan daerah penelitian

c. Fokus dari penelitian ini adalah pemetaan panas bumi yang bersifat kualitatif, dengan maksud untuk penentuan prioritas studi lanjut terkait daerah penelitian.

\subsection{Prosedur Penelitian}

\subsubsection{Data Utama}

Penelitian ini dilakukan dengan prosedur penelitian seperti yang ditunjukkan pada Gambar 4. Sebelum pengolahan data, dilakukan pengunduhan data Landsat 8 dan data gravitasi. Setelah itu, dilakukan pengolahan data untuk data Landsat terlebih dahulu melalui software ArcGIS. Pada data Landsat, penulis menggunakan band 4, 5, dan 10. Pada data Landsat band 10 , kita melakukan koreksi atmosfer dan sensor inframerah menggunakan Radiative flash transfer model dengan 65 simulation model untuk Landsat 4-7, dan Internal algorithm untuk Landsat 8 (U nited States Geological Survey, 2014).

Setelah itu, penulis melakukan perhitungan nilai NDVI menggunakan band 4 dan band 5 . Setelah didapatkan nilai NDVI, penulis melakukan perhitungan nilai emisi vitas. Seletah itu, penulis melakukan perhitungan nilai temperatur berdasarkan hasil koreksi data band 10 dan nilai emisivitas. Dengan demikan, hasil dari perhitungan tersebut merupakan persebaran nilai LST $\left({ }^{\circ} \mathrm{C}\right)$ yang berupa peta (Gambar 5). Data gravitasi diolah menggunakan software Oasis Montaj. Data gravitasi diplot menjadi peta anomali gravitasi Bouguer lengkap. Penulis melakukan pemisahan anomali dengan filter upward continuation, sehingga anomali regional dan residual dapat terpisah yang berupa peta regional dan peta residual (Gambar 5).

Setelah didapatkan anomali residual, penulis melakukan filter SVD pada data residual. H asil dari filter tersebut digunakan untuk menganalisa strukur patahan. Setelah itu, penulis melakukan slicing data menggunakan software Surfer untuk data residual yang sebelum dan sesudah difilter. Data hasil slicing (Gambar 6) akan digunakan untuk melakukan pengolahan inversi non-linear dan analisa SVD menggunakan softwarePython.

\subsubsection{Klasifikasi Temperatur dan Prioritas Studi Lanjut}

Nilai Land Surface Temperature (LST) diklasifikan seperti penelitian yang dilakukan oleh Tampubolon dkk. (2017), kemudian disesuaikan dengan nilai LST secara statistik dari software ArcGIS seperti yang ditunjukkan dengan Tabel $\mathbf{1}$. 


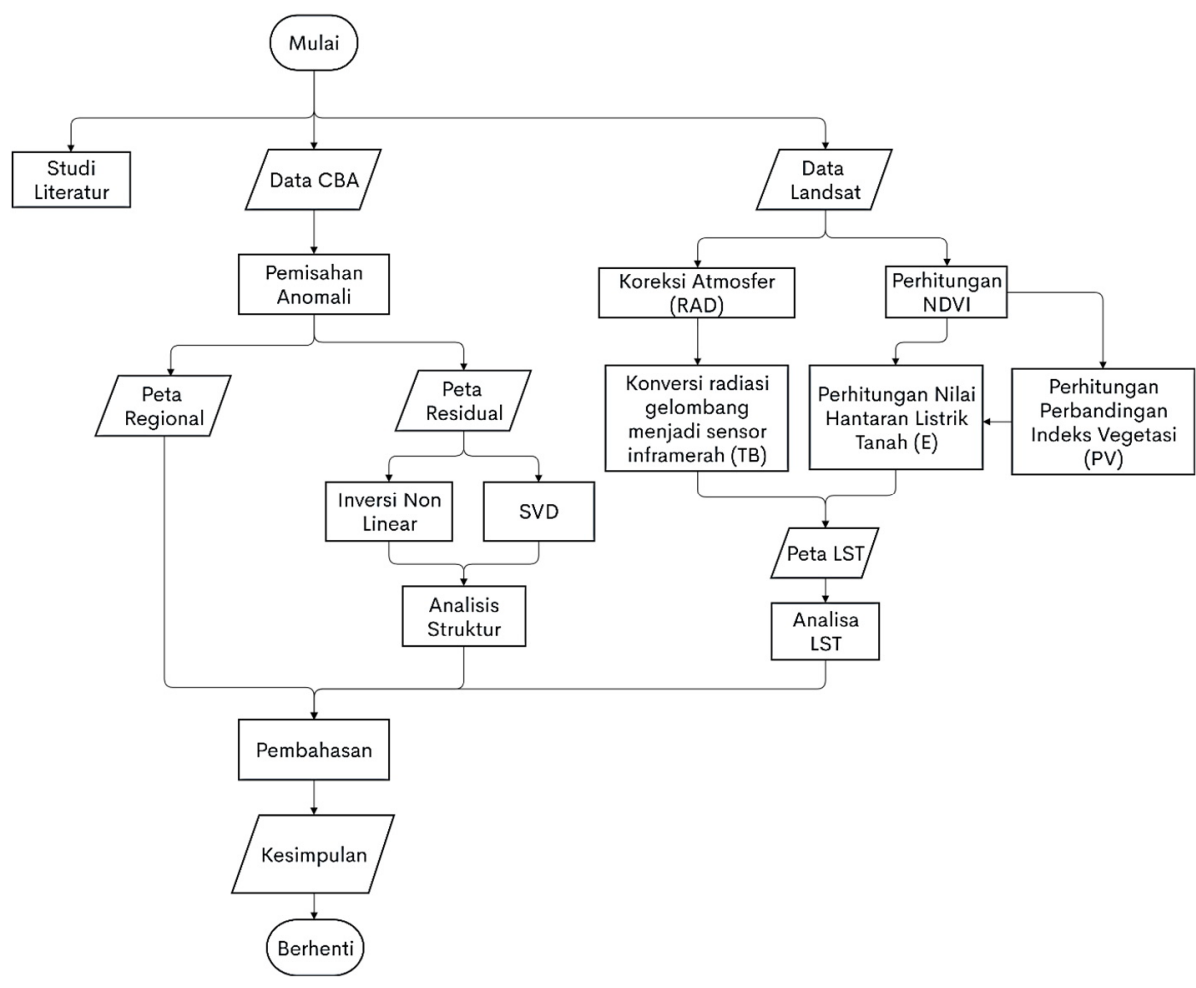

Gambar 4. Diagram alir penelitian secara keseluruhan.

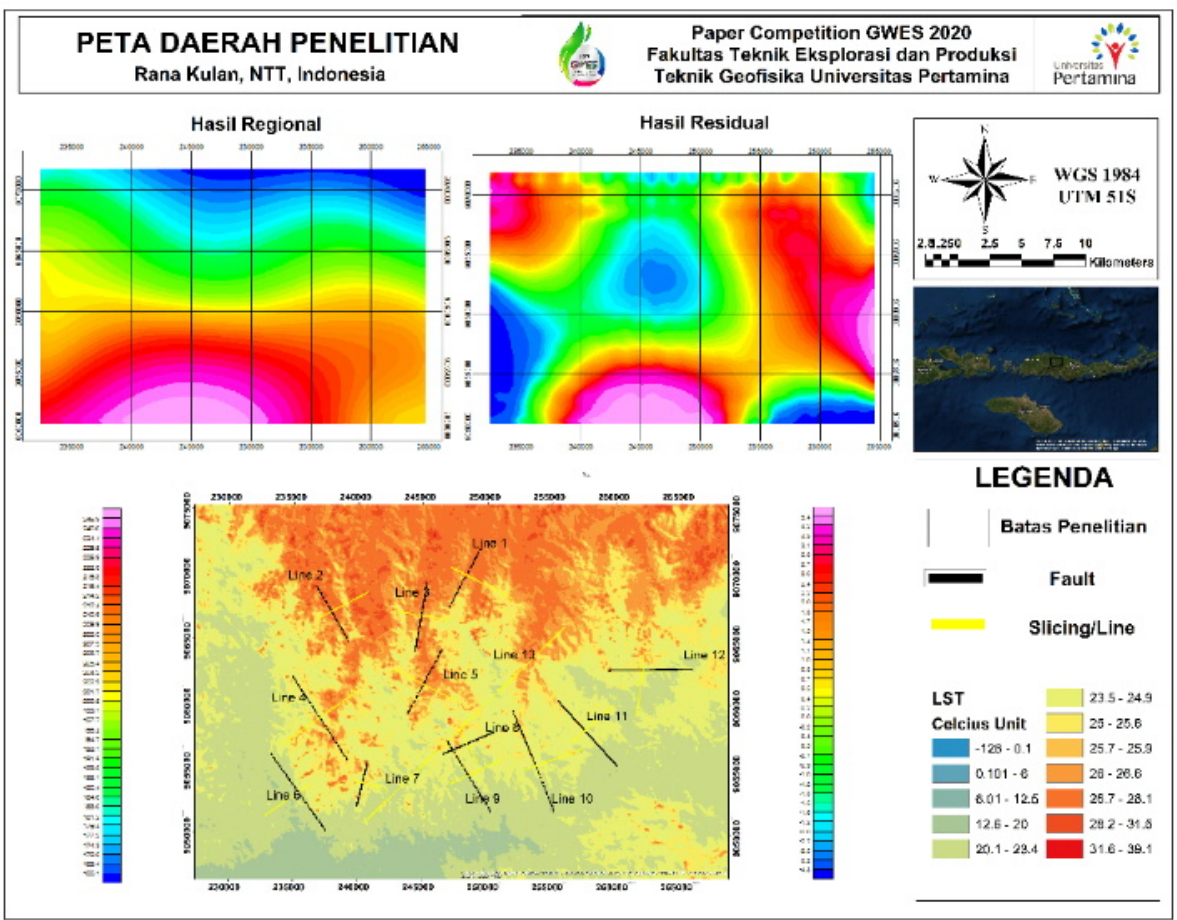

Gambar 5. O utput pengolahan data: peta anomali gravitasi Bouguer regional; peta anomali gravitasi Bouguer residual; peta Land Surface Temperature (LST). 
Tabel 1. Klasifikasi LST.

\begin{tabular}{|c|c|c|}
\hline No & Nilai LST $\left({ }^{\circ} \mathrm{C}\right)$ & Klasifikasi \\
\hline 1 & $-126-12.6$ & Rendah \\
\hline 2 & $12.7-26.5$ & Sedang \\
\hline 3 & $26.5-39.1$ & Tinggi \\
\hline
\end{tabular}

Kemudian analisa potensi panasbumi dilakukan berdasarkan lima klasifikasi prioritas pada Tabel 2 yang merujuk pada penelitian oleh Farras dkk. (2017).

Tabel 2. Prioritas Studi Lanjut.

\begin{tabular}{clc}
\hline No & \multicolumn{1}{c}{ Parameter } & Prioritas \\
\hline 1 & $\begin{array}{l}\text { LST tinggi, memiliki } \\
\text { strukur, dominasi } \\
\text { pemukiman } \\
\text { LST tinggi, terdapat }\end{array}$ & । \\
$2 \quad \begin{array}{l}\text { patahan/sesar, dominasi } \\
\text { vegetasi yang lebat }\end{array}$ & II \\
& $\begin{array}{l}\text { LST sedang, terdapat } \\
\text { patahan/sesar, dominasi } \\
\text { pemukiman } \\
\text { LST sedang, terdapat } \\
\text { patahan/sesar, dominasi } \\
\text { vegetasi lebat } \\
\text { LST rendah, } \\
\text { terdapat/tidak terdapat }\end{array}$ & III \\
\end{tabular}

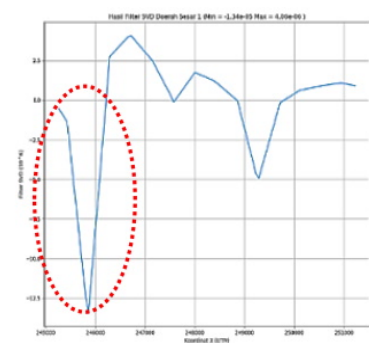

a)

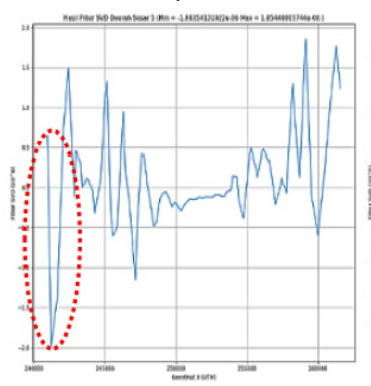

e)

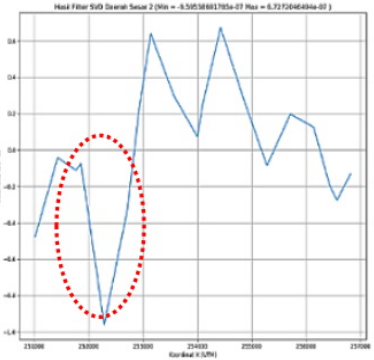

b)

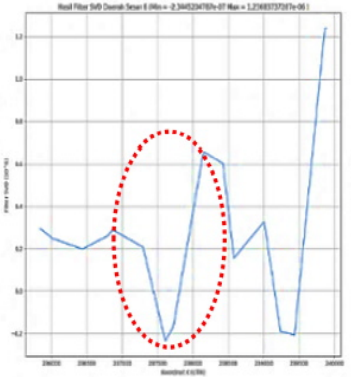

f)

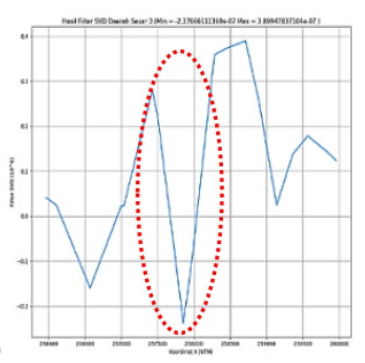

c)

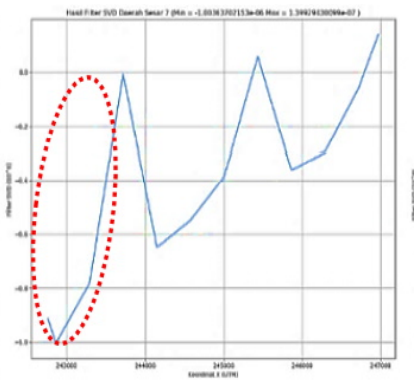

g)

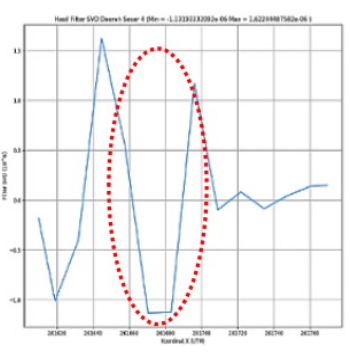

d)

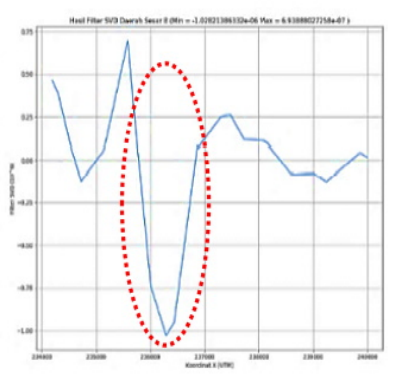

h) 


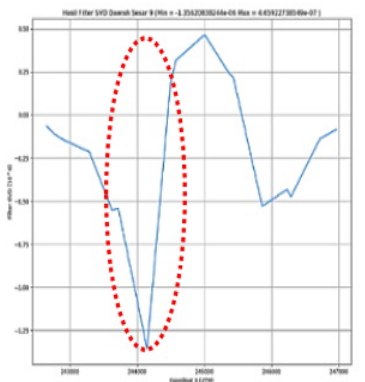

i)

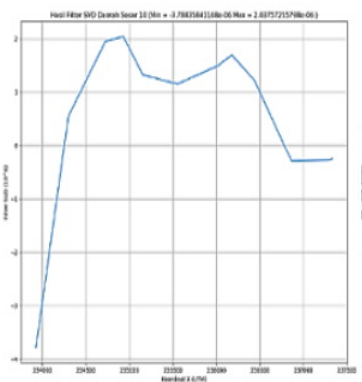

j)

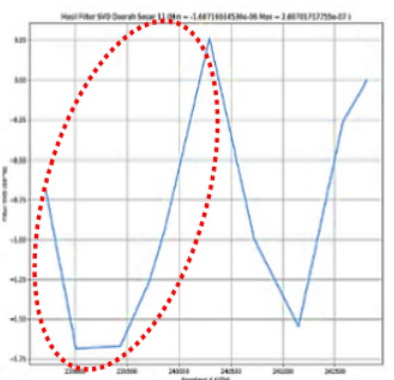

k)

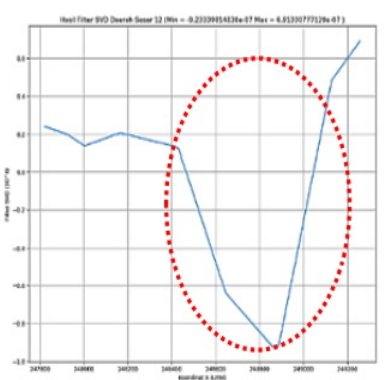

I)

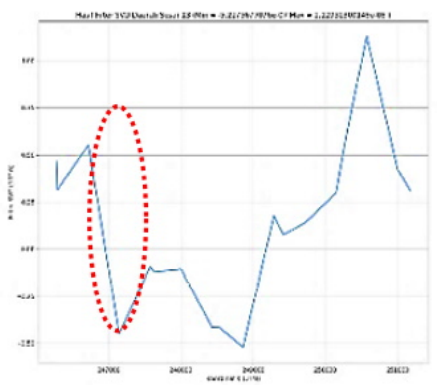

(m)

Gambar 6. Grafik SV D: (a) Line 1; (b) Line 2; (c) Line 3, (d) Line 4; (e) Line 5; (f) Line 6, (g) Line 7; (h) Line 8; (i) Line 9, (j) Line 10; (k) Line 11; (I) Line12, (m) Line 13.

Tabel 3. Hasil Pengolahan Data

\begin{tabular}{|c|c|c|c|c|c|c|}
\hline Line & $\begin{array}{c}\text { Koordinat } x \\
\text { (UTM) }\end{array}$ & $\begin{array}{l}\text { Absolute M ax } \\
\text { (mGal) }\end{array}$ & $\begin{array}{l}\text { Absolute M in } \\
\text { (mGal) }\end{array}$ & $\begin{array}{c}\text { Temperatur } \\
\left({ }^{\circ} \mathrm{C}\right)\end{array}$ & Formasi & $\begin{array}{c}\text { Keadaan } \\
\text { Lingkungan }\end{array}$ \\
\hline 1 & 245900 & $4.06 \times 10^{-6}$ & $13.4 \times 10^{-6}$ & $26.7-28.1$ & Bari & V egetasi Lebat \\
\hline 2 & 252300 & $0.672 \times 10^{-6}$ & $0.959 \times 10^{-6}$ & $25-28.5$ & Bari & Pemukiman \\
\hline 3 & 257800 & $0.389 \times 10^{-6}$ & $0.237 \times 10^{-6}$ & $26-26.6$ & $\begin{array}{c}\text { Bari, } \\
\text { Nangapanda }\end{array}$ & V egetasi Lebat \\
\hline 4 & $\begin{array}{l}261670- \\
261685\end{array}$ & $1.62 \times 10^{-6}$ & $1.13 \times 10^{-6}$ & $20.1-27$ & $\begin{array}{c}\text { Kiro, } \\
\text { Nangapanda }\end{array}$ & Pemukiman \\
\hline 5 & 242500 & $1.85 \times 10^{-6}$ & $1.98 \times 10^{-6}$ & $24-26.6$ & $\mathrm{~N}$ angapanda & Pemukiman \\
\hline 6 & 237600 & $1.236 \times 10^{-6}$ & $0.234 \times 10^{-6}$ & $12.6-25$ & Kiro & Pemukiman \\
\hline 7 & 242200 & $0.139 \times 10^{-6}$ & $1.003 \times 10^{-6}$ & $20.1-25.5$ & $\begin{array}{c}\text { Kiro, } \\
\text { Nangapanda } \\
\text { Kiro, }\end{array}$ & Pemukiman \\
\hline 8 & 2326300 & $0.693 \times 10^{-6}$ & $1.028 \times 10^{-6}$ & $20.1-26$ & $\begin{array}{l}\text { Nangapanda, } \\
\text { W aihekang }\end{array}$ & Pemukiman \\
\hline 9 & 244100 & $4.66 \times 10^{-6}$ & $1.356 \times 10^{-6}$ & $12.6-24.9$ & Kiro & Pemukiman \\
\hline 10 & - & $2.037 \times 10^{-6}$ & $3.78 \times 10^{-6}$ & $12.6-24.9$ & Kiro & Pemukiman \\
\hline 11 & 241200 & $0.26 \times 10^{-6}$ & $1.687 \times 10^{-6}$ & $12.6-25$ & $\begin{array}{c}\text { Kiro, Bari, } \\
\text { Diorit Kuarsa }\end{array}$ & Pemukiman \\
\hline 12 & 248900 & $0.691 \times 10^{-6}$ & $0.923 \times 10^{-6}$ & $12.6-27$ & $\begin{array}{c}\text { Kiro, Bari } \\
\text { Bari, } \\
\text { Nangapanda, }\end{array}$ & V egetasi Lebat \\
\hline 13 & 247250 & $1.129 \times 10^{-6}$ & $0.522 \times 10^{-6}$ & $12.6-28.1$ & $\begin{array}{c}\text { Waihekang, } \\
\text { Kiro, Diorit } \\
\text { Kuarsa }\end{array}$ & Pemukiman \\
\hline
\end{tabular}


Hasil tersebut menunjukkan bahwa kemenerusan pada peta litologi dapat dikonfirmasi sebagai sesar kecuali untuk line 10. Selain itu, line 13 yang melewati line 9 menjadi validasi bahwa kemenerusan line 9 di peta litologi benar merupakan sesar karena dapat ditunjukkan baik oleh line 9 maupun line 13. Penelitian yang dilakukan oleh Sarkowi (2011) menyatakan bahwa jenis sesar dapat ditentukan berdasarkan nilai absolut minimum dan maksimum dari SVD. A pabila nilai absolut maksimum lebih besar dari absolut minimum menunjukkan patahan normal (turun), dan sebaliknya.

Berdasarkan rujukan penelitian tersebut, pada Tabel 4 ditunjukkan bahwa dari 12 line yang terindikasi patahan (sesar), line 3, 4, 6, dan 13 menunjukkan jenis patahan normal. Sedangkan line $1,2,5,7,8,9,11$, dan 12 menunjukkan jenis patahan naik. Keberadaan patahan ini merupakan asal mula manifestasi dari panasbumi. Hal ini juga didukung dari keberadaan mata air panas di sebelah barat tidak jauh dari daerah penelitian. Sehingga semualineselain line 10 memiliki potensi panas bumi yang cukup tinggi dari keberadaan patahan.

Hasil pengolahan data Landsat menghasilkan nilai temperatur dari daerah penelitian seperti yang ditunjukkan oleh Tabel 3. Persebaran nilai LST berada pada rentang ($126)^{\circ} \mathrm{C}-39.1^{\circ} \mathrm{C}$, dengan nilai LST tertinggi terletak pada line 2 dan nilai LST terendah terletak pada line 6. Berdasarkan klasifikasi temperatur Tabel 1, line dengan temperatur rendah adalah line 6, 9, dan 11 . Sedangkan daerah dengan temperatur sedang adalah line 4, $5,7,8,10$, dan 12. Dan daerah dengan temperatur tinggi adalah line 1, 2, dan 3 . Temperatur permukaan yang tinggi merupakan indikasi keberadaan manifestasi panasbumi. Sehingga line yang memiliki nilai temperatur tinggi memiliki potensi panasbumi yang lebih tinggi dibanding dengan linelain yang memiliki nilai temperatur permukaan lebih rendah.

Kasbani (2009) menyatakan bahwa batuan penyusun panasbumi merupakan batuan vulkanik khususnya batuan berumur $\mathrm{M}$ iosen Tengah yang memiliki kandungan AndesitBasalt. Formasi litologi penyusun daerah penelitian ditunjukkan oleh peta litologi (Gambar 2), dimana daerah penelitian tersusun atas enam formasi dan tiga diantaranya memiliki kandungan AndesitBasalt. Tiga formasi tersebut adalah Formasi Bari, Formasi Kiro, dan Formasi Nangapanda. Seluruh line penelitian memiliki satu atau lebih dari tiga formasi tersebut. $\mathrm{Hal}$ tersebut menunjukkan bahwa derah penelitian memiliki kandungan batuan penyusun panasbumi sehingga potensi panasbumi juga tinggi.

Selain faktor pendukung potensi panasbumi, keadaan lingkungan juga perlu diperhatikan dalam melakukan eksplorasi dan eksploitasi lanjutan pada daerah penelitian. Keadaan lingkungan mempengaruhi kemudahan akses transportasi menuju lokasi dan biaya pembangunan infrastruktur. V egetasi yang lebat dapat menjadi rintangan akses menuju lokasi, dan mengakibatkan pengeluaran biaya pembangunan infrastruktur menjadi lebih tinggi untuk membangun jalan sebagai akses transportasi. Sedangkan pemukiman dapat menguntungkan dalam kemudahan akses transportasi karena telah tersedia dan dapat mengurangi biaya pembangunan infrastruktur. Berdasarkan pertimbangan tersebut, maka line dengan keadaan lingkungan berupa pemukiman memiliki potensi panasbumi lebih tinggi daripada line dengan keadaan lingkungan berupa vegetasi yang lebat.

Berdasarkan hasil inversi non-linear pada line 13 (Gambar 7) terdapat stuktur yang ditandai dengan perbedaan kontras densitas dan hal tersebut sesuai dengan peta geologi. 
Tabel 4. Rangkuman karateristik setiap line.

\begin{tabular}{|c|c|c|c|c|c|}
\hline Line & Sesar & LST & Keadaan Lingkungan & $\begin{array}{c}\text { Andesit- } \\
\text { Basalt }\end{array}$ & Prioritas \\
\hline 1 & Naik & Tinggi & V egetasi Lebat & $\checkmark$ & II \\
\hline 2 & Normal & Tinggi & Area Pemukiman & $\checkmark$ & I \\
\hline 3 & Naik & Tinggi & V egetasi Lebat & $\checkmark$ & II \\
\hline 4 & Naik & Sedang & Area Pemukiman & $\checkmark$ & III \\
\hline 5 & Normal & Tinggi & Area Pemukiman & $\checkmark$ & I \\
\hline 6 & Naik & Rendah & Area Pemukiman & $\checkmark$ & V \\
\hline 7 & Normal & Sedang & Area Pemukiman & $\checkmark$ & III \\
\hline 8 & Normal & Sedang & Area Pemukiman & $\checkmark$ & III \\
\hline 9 & Normal & Rendah & Area Pemukiman & $\checkmark$ & V \\
\hline 10 & Tidak ada & Rendah & Area Pemukiman & $\checkmark$ & V \\
\hline 11 & Normal & Rendah & Area Pemukiman & $\checkmark$ & V \\
\hline 12 & Normal & Sedang & V egetasi Lebat & $\checkmark$ & IV \\
\hline
\end{tabular}
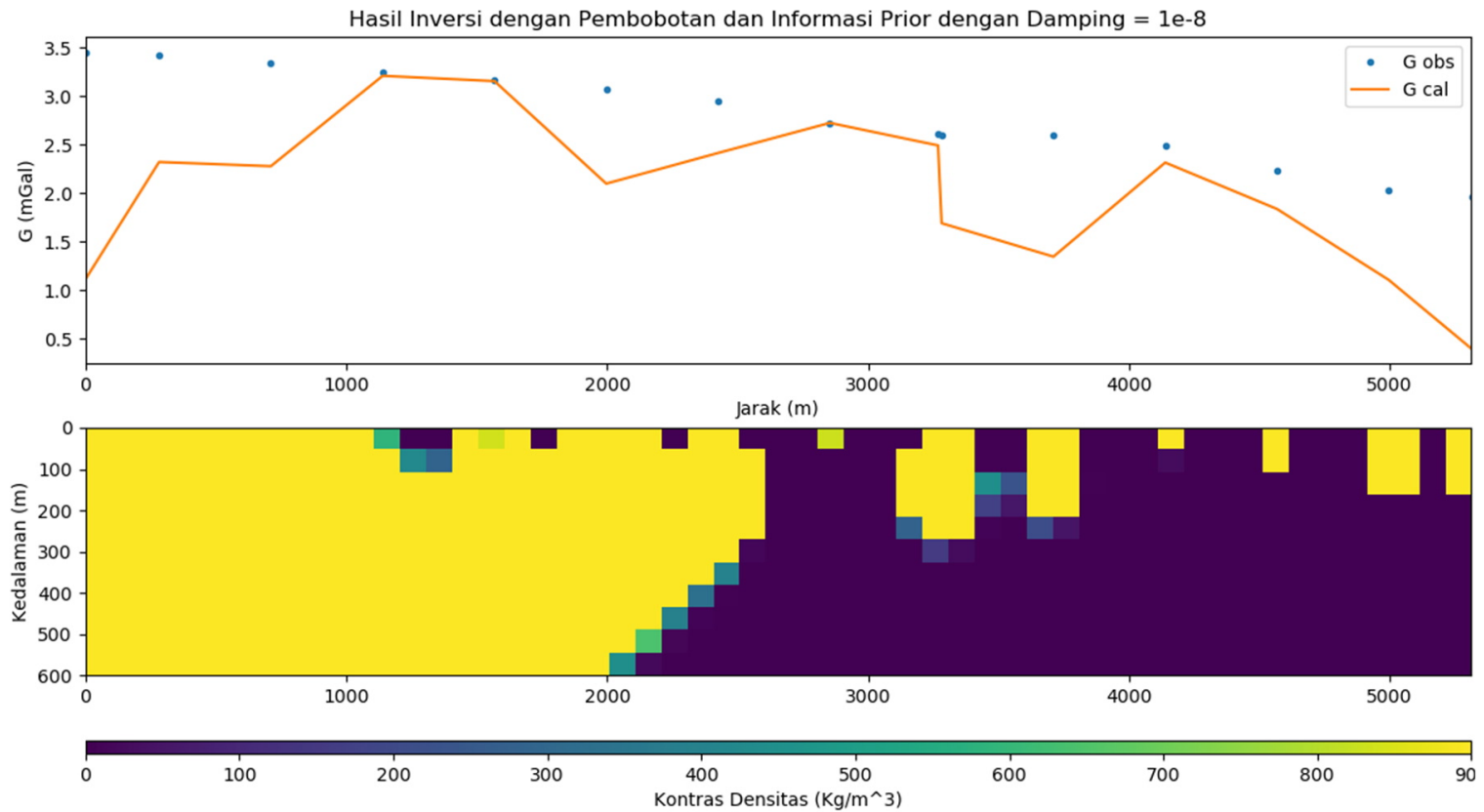

Gambar 7. Hasil inversi non-linear dengan error RMS 1.

\section{KESIMPULAN}

a. Hasil potensi panasbumi paling tinggi berada pada line 2 dan line 5, dikarenakan pada line tersebut menunjukkan adanya keberadaan sesar dengan temperatur yang tinggi serta kondisi lingkungan yang didominasi oleh pemukiman.

b. Hasil dengan potensi panasbumi paling rendah berada pada line $6,9,10$, dan 11 , dengan hasil menunjukkan adanya keberadaan/tidak keberadaan sesar dengan temperatur yang rendah serta kondisi lingkungan yang didominasi oleh pemukiman/vegetasi lebat.

c. Kemenerusan yang ditunjukkan pada peta geologi merupakan struktur patahan baik sesar normal maupun sesar naik dari hasil grafik nilai SVD. Struktur berupa sesar 
tersebut tervalidasi dari line 13 dan line 9 yang memotong struktur kemenerusan yang sama.

\section{UCAPAN TERIMA KASIH}

Penulis mengucapkan terima kasih sebesarbesarnya kepada Bapak Sandy Kurniawan, P.hD., dan Dicky A hmad Zaky, M.T., selaku dosen pembimbing yang telah memberikan bimbingan, arahan, saran, dan koreksi dalam menyusun paper ilmiah ini. Tak lupa kami mengucapkan terima kasih kepada keluarga, teman-teman, dan orang tua yang selalu memberikan dukungan dalam bentuk moril maupun materi.

\section{DAFTAR PUSTAKA}

A riyadi, W. (2007). Estimasi Evapotranspirasi Spasial M enggunakan Suhu Permukaan Darat (LST) Dari Data Modis Terra/Aqua dan Pengaruhnya Terhadap Kekeringan [Institut Pertanian Bogor]. http://repository.ipb.ac.id/handle/123456789/ 33247

Darman, H. (2000). An outline of the geology of Indonesia.

Direktorat Panas Bumi. (2017). Potensi Panas Bumi Indonesia. Direktorat Jendral Energi Baru, Terbarukan dan Konservasi Energi. Kementerian Energi dan Sumber Daya $M$ ineral.

Farras, N., Sukmono, A., \& Bashit, N. (2017). Analisis Estimasi Energi Panas Bumi M enggunakan Citra Landsat 8 (Studi Kasus: Kawasan Gunung Telomoyo). Jurnal Geodesi Undip, 6(4), 371- 380.

Hinze, W., vonFrese, R., \& Saad, A. (2013). Gravity and Magnetic Exploration, Principles, Practices, and A pplications by Hinze, vonFrese and Saad, 2013.

H utahaean, J., \& Silaban, R. N. (2017). Penentuan Struktur Bawah Permukaan Panas Bumi Tinggi Raja Kabupaten ismalungun Berdasarkan Data Magnetik. Jurnal Einstein, 6, 42-47.

Kasbani. (2009). Status Penyelidikan, Potensi dan Tipe Sistem Panas Bumi. Sumber Daya Panasbumi Indonesia. http://psdg.bgl.esdm.go.id/index.php?option $=$ com_content $\&$ view $=$ article $\& i d=841 \&$ Itemid $=611$

Koesoemadinata, S., N oya, Y., \& Kadarisman, D. (1994). Peta Geologi Lembar Ruteng, Nusa Tenggara, Skala 1:250.000. Pusat Penelitan dan Pengembangan Geologi.

M arkham, B. L., \& Barker, J. L. (1985). Spectral characterization of the LANDSAT Thematic $M$ apper sensors. International Journal of Remote Sensing, 6(5), 697-716. https://doi.org/10.1080/01431168508948492

Tampubolon, T., A bdullah, K., Lim, H. S., \& Yanti, J. (2016). The identification of geothermal with geographic information system and remote sensing in distric of Dolok Marawa. AIP Conference Proceedings, 1712, 30011. https://doi.org/10.1063/1.4941876

Telford, W. M., Geldart, L. P., \& Sheriff, R. E. (1990). Applied Geophysics (2nd ed.). Cambridge University Press. https://doi.org/10.1017/CB0 9781139167932

U nited States Geological Survey. (2014). Provisional Landsat 8 Surface Reflectance Data Available. Diakses pada 20 Agustus 2020 dari:http://landsat.usgs.gov/about_LU_Specia I_Issue_3.php Sarkowi, M. (2011). Modul Praktikum Pengolahan Data Gayaberat.

U nited States Geological Survey. (2016). Landsat 8 (L8) Data Users Handbook. United State of America, $106 \mathrm{p}$.

Weng, Q., Lu, D., \& Schubring, J. (2004). Estimation of land surface temperature-vegetation abundance relationship for urban heat island studies. RemoteSensing of Environment, 89(4), 467-483.

https://doi.org/https://doi.org/10.1016/j.rse.2 003.11 .005 